\title{
Social responsibility development in the conditions of globalization: financial flows focus
}

\author{
Oksana Portna ${ }^{* 1}$, Svitlana Kachula ${ }^{2}$ and Liubov Lysiak ${ }^{2}$ \\ ${ }^{1}$ V. N. Karazin Kharkiv National University, 4 Svobody Sq., Kharkiv, 61022, Ukraine \\ ${ }^{2}$ University of Customs and Finance, 4/2 Vernadskogo av., Dnipro, 49000, Ukraine
}

\begin{abstract}
The article deals with social responsibility system development of the state, business, society. It is shown that the characteristic of development and the result of social responsibility of the state, business, society is the high quality of socio-economic development, balancing the interests of all participants in social relations. Modern complex social relations actualize social issues both within individual countries and in the world dimension. The problems of social responsibility of the state, business, and society concern a wide range of economic, social, financial, environmental and political aspects. The article presents generalized standards and conditions for the development of socially responsible state, business, and society, which are mediated by financial flows. A meaningful characteristic of state, business and society social responsibility development is the social relations institutional participants financial flows focus, which should be considered in unity with the global system and relevant world processes during globalization. The problems of financial flows direction in the conditions of financial and economic globalization are considered. In Ukraine, social responsibility of the state, business, society is non-systemic, fragmentary, situational.
\end{abstract}

\section{Introduction}

Problems of social responsibility not only of business but of the state, the population both within the borders of any country and in the world remain relevant because of the deepening of socio-economic asymmetries in the context of the development of globalization processes and the modern complex configuration of the world financial and economic order and countries development. his gives an additional impetus to deepen the research of this problem, especially in terms of the direction of financial flows in a situation where institutional actors are trying to accumulate considerable amounts of money resources. This provides an additional impetus for deepening the research of this issue, especially as regards the orientation of financial flows in a situation when institutional actors are trying to concentrate considerable amounts of money resources.

\footnotetext{
Corresponding author: portna@karazin.ua
} 
The world scientific community representatives, M. Porter [1], T. Wilson [2] and others, made a significant contribution to the study of a wide range of corporate social responsibility issues. The thorough processing of the globalization processes was carried out by M. Waters [3], T. Levit [4], and others. Fundamental researches of financial imbalances in the conditions of globalization were carried out by P. Krugman [5], J. Stiglitz [6].

Currently, "social responsibility" category theoretical aspects are analysed in separate sections of the state, business, society. However, the aspect of the development of social responsibility of the state, business, society as a system, especially in the context of globalization processes, characterized by a certain orientation of financial flows, remains unexplored. Insufficient attention is paid to the definition of social relations subjects socially irresponsible behaviour.

The purpose of this article is to consider social responsibility of the state, business, society as a systemic phenomenon, to determine the quantitative and qualitative limits of social responsibility and/or irresponsibility of the authorities, business, and society of the country, the basis of which is the focus of financial flows in the globalization dimension.

In today's conditions of global and national financial and economic crises, the spread of social tension, development rates inhibition, etc. one of the important concepts of the world order is the states, business and society social responsibility development, which is consistent with the concept of sustainable development. Different manifestations of social responsibility of the state, business, society are characterized by different characteristics, influence of various factors actions, formation and implementation of the system of social responsibility principles. A significant characteristic of development and the result of social responsibility of the state, business, society is the high quality of socio-economic development, balancing the interests of all participants in social relations.

Modern complex social relations actualize social issues both within individual countries and in the world dimension, reflected in the global growth gap between income and wealth of the poor and the rich, the economic inequality of the development of countries and their population, large differences in the efficiency of sectoral economic activity, etc.

Existing theoretical and practical developments of social responsibility various aspects, mostly in form and content, relate to the formulation of individual social actions of the state, business $[1 ; 2]$, society, etc., and the declaration of the influence of institutions (official and informal, state and non-state) on the rules and norms of behaviour and obligatory observance by members of social relations.

The problems of social responsibility of the state, business, and society concern a wide range of economic, social, financial, environmental, political, and other aspects. But these aspects are mostly considered within individual states, individual businesses. In our opinion, this is a simplified approach to the problem of development of social responsibility, especially in the context of the globalization processes strengthening. That is, it is about a system of social responsibility, in which all participants in social relations, namely the state, business and society, mutually influence and interact.

\section{Discussion}

All members of public relations (state, business, society) in order to realize their interests declaratively define the elements of social responsibility. The state social responsibility is determined by the very nature of the state and is embodied in ensuring each person's conditions for an acceptable standard of living, establishing sound social standards and ensuring their observance, preventing anti-social behaviour caused by poverty, chronic diseases, inability to receive education, etc. At the same time, the state aims to ensure equity, reduce income inequality by redistributing it in favour of those who are objectively unable to work and the poor. An important tool for achieving the stated goal is the state 
financial policy and its main directions: fiscal, monetary, investment, social and others. Using the financial policy tool, the state makes indexation of incomes, price regulation, labour market, establishment of the minimum wage, state social transfers, regulates the labour market and others. The targeted and effective financial flows direction, considering the harmonization of the interests of the state, business and society, involves the comprehensive and responsible use of the instruments of state financial policy.

According to the world practice, the criteria for assigning a business to a socially responsible (full payment of taxes in accordance with the legislation, production and sales of quality products, staff development, social investment, charitable and sponsorship projects implementation, etc.), more and more Ukrainian companies can be called socially responsible by certain criteria. Major Ukrainian business mainly implements charity and sponsorship projects (accompanied by their aggressive advertising in the mass media), provides social investments, both internal (training of personnel directly in the workplace) and external ones (development of local communities, realization of certain public initiatives, protection of the environment, landscaping, etc.). Business is responsible for the organization's culture, compliance with business and corporate ethics, and the socioeconomic implications of managerial decisions for its own staff and society. At the same time, it should be noted that the principles of social responsibility of business in Ukraine are being implemented slowly and implemented in the most part fragmentary.

If we consider the standards and conditions of development of social responsibility of the state, business and society, then we can cite such as: development of economy, business, creation of workplaces, life quality improvement, increase of incomes, increase of solvency of the population, growth of consumer demand and commodity circulation, expansion of the base taxation, payment of taxes in full, formation of expenditures on budgets on the basis of socially oriented state, etc.

In Ukraine, social responsibility of the state, business and society is non-systemic, fragmentary, situational. According to the study by O. Moroz [7, p. 142], an efficient and effective system of realization of harmonizing the interests of the state, business, society and ensuring at all levels mutually beneficial cooperation between bodies of all levels of the state (regional, municipal) authorities, business owners (employers) and employees' representatives (trade union organizations), which will ensure the prevention and/or mitigation of contradictions that arise in the process of social dialogue is currently practically absent. An optimal system of reconciliation of interests can only be created through the achievement by the parties of the social dialogue of a fundamental consensus on the issues: preservation and maintaining the stability of the development of the national economy; promotion of socio-economic growth and competitiveness of business; joint regulation and control in the field of economic and social policy by the parties of social partnership (dialogue); support of social peace.

In our opinion, the substantive characteristic of the development of social responsibility of the state, business, and society is the focus of financial flows of all institutional participants in social relations on social development policy implementation. This is especially significant in the context of globalization. In the context of globalization processes, financial determinants of deepening the asymmetries of global development [8], asymmetry and paradoxes of financial globalization [9] the problems of social responsibility of the state, business, society should be considered in unity with the global system and relevant global processes.

According to N. Kravchuk [8, p. 346-347], the transformational processes in the world economy have significantly accelerated and become systematic, creating the preconditions for the formation of a global model of economic development. The profound qualitative changes in the character and driving forces of the economic system development, with the prevalence of global forms of its functioning on the basis of the internationalization of production and exchange, the growth of the level of trans nationalization and the national 
economies integration, lead to the modernization of a modern market economy and the adoption of universal life standards.

However, on the other hand, globalization processes are challenging, especially with regard to the accumulation of global financial resources and financial flows direction. According to Z. Lutsyshyn [9, p. 111], globalization cannot progress without the financial resources of world markets, which evolve under the direct influence of globalization trends. Globalization of finance as an important component of the globalization of the world economy is based on a powerful over-scale transfer of monetary capital between countries in international financial flows. The negative effect of financial globalization is, among other things, chronic debt crisis that involves dozens of countries, mainly developing countries. The economic backwardness of developing countries is increasing from the advanced ones. This gap often contributes to fundamental differences in the political and social structures of developed and backwards countries. And as a result of these differences, the dependence of the backward countries on the advanced ones increases.

That is, in the conditions of deepening of globalization processes, strengthening of financial globalization, the direction of financial flows of all subjects of national economies are indicators of social responsibility. Thus, the volume of public debt of Ukraine is characterized by significant amounts of consolidated budget expenditures for debt servicing [10, p. 226]. In 2013, debt servicing amounted to UAH 33,172.1 million; in 2014 - UAH 49,434.6 million; in 2015 - UAH 86,172.7 million; in 2016 - UAH 96,105.2 million; and in 2017 - UAH 110,578.2 million. If we consider the dynamics of the quantitative and qualitative indicators of the consolidated budget of Ukraine 2016-2017, then the dynamics of consolidated budget revenues is $129.9 \%$, while the state debt service is $115.1 \%$; the expenditure dynamics is $126.5 \%$; the dynamics of expenditures on social protection and social security $-110.6 \%$; the dynamics of expenditures on environmental protection 117.5\%. The share of expenditures of the Consolidated Budget of Ukraine in 2017 for servicing the state debt is $10.5 \%$; and spiritual and physical development $-2.3 \%$; for the protection of the environment $-0.7 \%$. The situation when the services of interests of external borrowers spend more resources than national development (with the tendency of debt total amount growth and its maintenance), testifies to the socially irresponsible activity of the state, business, population, that is, the entire system of national social and economic relations.

As I. Chugunov notes, the problem of fiscal financial flows, the development of financial relations in Ukraine is always particularly acute [11]. Chugunov also argues that in order to increase the efficiency and balance of budget flows, it is necessary to implement balanced budgetary regulation during a certain period in order to positively influence its economic growth, and budget policy should be determined on the basis of the cyclical nature of economic development, as well as the state of public finances, stock stability of the budgetary system in the light of the existing institutional environment [12].

When analysing direct investment (share capital) from Ukraine in the economies of the world, it should be noted that more than $90 \%$ of resources are directed to offshore (Table $1)$.

Table 1. Direct investment (share capital) from Ukraine (USD million) [10]

\begin{tabular}{|l|c|c|c|c|c|c|c|}
\hline \multirow{2}{*}{ Indexes } & \multicolumn{6}{|c|}{ Direct investment on January 1 } & December \\
\cline { 2 - 8 } & 2012 & 2013 & 2014 & 2015 & 2016 & 2017 & 31,2017 \\
\hline Total & 6456.2 & 6588.7 & 6702.9 & 6456.2 & 6315.2 & 6346.3 & 6339.8 \\
\hline Cyprus & 5899.7 & 5917.6 & 5925.1 & 5926.1 & 5923.7 & 5930.5 & 5932.5 \\
\hline $\begin{array}{l}\text { Proportion: } \\
\begin{array}{l}\text { Cyprus / } \\
\text { Total\% }\end{array}\end{array}$ & 91.4 & 89.8 & 88.4 & 91.8 & 93.8 & 93.4 & 93.6 \\
\hline
\end{tabular}


If we consider the factor of the constant decrease of the UAH to the US dollar, in the analysed period [10], we can conclude that in the UAH equivalent, the volume of direct investment in offshore is significantly increasing.

\section{Results}

Such an orientation of the national economy financial flows to investment activities in the conditions of financial globalization actually demonstrates both the social irresponsibility of the national business and the irresponsible behaviour of the state, society as a system, after all, businesses withdraw resources in the offshore, and the state at the legislative and executive levels does not restrict leakage of resources from the national economy.

That is, for example, indicators of social irresponsibility of the state are the reduction of social expenditures, low incomes, low domestic demand due to the low purchasing power of the national currency, the growth of external public debt, etc. Indicators of social irresponsibility of the business are shadow activity, tax evasion, unofficial income, low wages of hired workers, withdrawal from the offshore, etc. For example, one of the indicators of corporate social responsibility is conscientious payment of taxes in accordance with the current legislation. At the same time, the results of tax planning and unplanned controls carried out by the State Fiscal Service of Ukraine during 2016-2018 show that taxpayers (large, medium and small businesses) every year violate tax laws and do not fully pay taxes. Thus, a significant amount of underpayment to the budget of value added tax, income tax, excise tax and land tax was revealed. In the sectoral section in 2018: 140 subjects of economy with revenues of over 200 billion UAH were inspected from oil and gas industry and 5.8 billion UAH were added to the budget; in the construction industry 372 enterprises with incomes of more than 33 billion UAH and paid to the budget by 850 million UAH, in the processing and scrap metal trade - 21 business entities with revenues of more than 70 billion UAH, taxes were added up to 570 million UAH [13]. The percentage of tax control of enterprises of large, medium and small businesses during the period 2016-2018 is decreasing and averaging over the period of about $60 \%$ [13]. The control over 2016-2018 covers every fifteenth largest and mid-sized business entity that, judging by the data presented, is socially irresponsible.

Indicators of social irresponsibility of the population are evasion from work and duties, passivity to increase their own professional qualification level, careless attitude towards their health and health of others, shadow/illegal activity and obtaining shadow/illegal income, therefore tax evasion, and so on.

According to the Corporate Social Responsibility Development Promoting Strategy in Ukraine for the Period up to 2020, the necessity of developing social responsibility of business in Ukraine is determined by the following factors: low level of corporate culture; legal nihilism; low level of public awareness of the role of business; Ukrainian companies secrecy from the public; uneven consideration of interests of stakeholders [14]. Unfortunately, the Strategy does not take into account the need of the state, society and each of its members social responsibility development, which is a prerequisite for the harmonization of social and economic social relations.

\section{Conclusion}

Thus, a number of aspects of the state, business and society social responsibility development are updated, namely, the clear delimitation of quantitative and qualitative national and global indicators, as well as the quality of information support, information base [15], for monitoring of state, business, population social responsibility and/or irresponsibility. 
For the development of the system of social responsibility of the state, business, society, especially in the context of deepening globalization processes, it is important:

- to create the appropriate institutional mechanisms that can neutralize the influence of negative factors on the development of social responsibility of business, state, society, promote integrated and responsible use of instruments of state financial policy regarding purposeful and effective direction of financial flows for taking into account the state, business, society interests harmonization;

- to create a modern high-quality information base for monitoring the state, business, and population social responsibility system;

- to introduce public control over observance of the state, business, society socially responsible behaviour;

- align the interests of social dialogue participants based on consideration of their real needs and capabilities based on responsible government financial policy;

- to define methodological and methodical principles and recommendations concerning indicators of the state, business, society social responsibility system; and

- to develop criteria for assessing the degree of social responsibility of the state, business, society.

\section{References}

1. M. Porter. Harvard Business Review, 84 (12), 78-94. (2009)

2. Th. Wilson. Brotherhood of St. Laurence's Research \& Policy Centre. CSR and banks: the role that banks could and should play in addressing financial exclusion. Fitzroy Vic. (2008)

3. M. Waters. London; N.Y.: Routledge. Globalization (Key Ideas). 272. (1995)

4. T. Levitt. Harvard Business Review. The Globalization of Markets. № 61 (3). P. 92102. (1983)

5. P. Krugman. The New York Times. Deficits saved the world, available at: https://krugman.blogs. nytimes.com/2009/07/15/deficits-saved-the-world/

6. J. Stiglitz. New York: WW Norton \& Co. Freefall: America, Free Markets and the Sinking of the World Economy. 361 (2010)

7. O. S. Moroz. Ekonomika promyslovosti - Economy of The Industry, 4 (65), 135 - 143. (2013).

8. N. Ya. Kravchuk. Naukovi zapysky. Seriya Ekonomika. 15, 346 - 356. (2010).

9. Z. Lutsyshyn. Mizhnarodna ekonomichna polityka - International Economic Policy, 1-2, 88-121. (2008).

10. Werner I. Ye. (Eds.). Statystychnyi chorichnyk Ukrainy za 2017 rik. Kiyv. (2018).

11. I.Ya. Chugunov. Visnyk Kyivskoho natsionalnoho torgovelno-ekonomichnogo universytetu, 4, 13-22. (2011)

12. I.Ya. Chugunov. Visnyk Kyivskoho natsionalnoho torgovelno-ekonomichnogo universytetu, 5, 64-77. (2014)

13. Zvit Derzavnoij fiskalnoi sluzhby Ukrainy za 2016-2018 roky. fvailable at: http://sfs.gov.ua/data/files/240396.pdf

14. Strategiya spriyannya rozvytku sotsialnoi vidpovidalnosty biznesu v Ukraini na period do 2020 roku, available at: http://www.svb.org.ua/sites/default/files/201309 strategiya spriyannya_rozvitku_svb_v_ukrayini.pdf.

15. N. U. Ershova. Aktualni problemy ekonomiky, 8 (158), 368 - 374. (2014) 